NIST

PUBLICATIONS

\section{An Experimental Study of Top Vented Compartment Fires}

\section{King-Mon Tu}

U.S. DEPARTMENT OF COMMERCE Natlonal Instltute of Standards and Technology Bullding and Fire Research Laboratory Gaithersburg, MD 20899

U.S. DEPARTMENT OF COMMERCE Robert A. Mosbacher, Secretary NATONAL INSTIUUTE OF STANDARDS AND TECHENOLOGY

John W. Lyons, Director

QC

100

.456

\#4499

1991

C. 2 



\section{An Experimental Study of Top Vented Compartment Fires}

\section{King-Mon Tu}

U.S. DEPARTMENT OF COMMERCE Natlonal Institute of Standards and Tochnology

Bullding and Fire Research Laboratory Galthorburs, MD 20899

Fobruary 1991

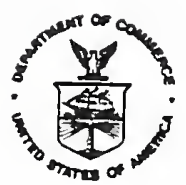

US. DJPARTMENT OF COMMERCE Robert A Moobacher, Secretary NATIONAL INSTIUUTE OF STANDARDS AND TECHNOLOGY

John W. Lyons, Director 

TABLE OF CONTENTS

Page

TABLE OF CONTENTS

LIST OF TABLES

iv

LIST OF FIGURES

iv

ABSTRACT

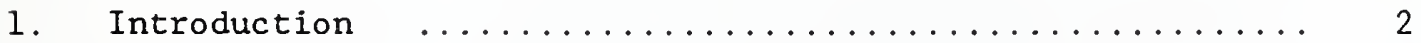

2. The Flow of Gases Through Horizontal Ceiling Vents ..... 3

3. Experimental Facilities

for the Top Vented Compartment Fires $\ldots \ldots \ldots \ldots \ldots \ldots \ldots$........... 4

4. The Compartment Fire Test Procedure $\ldots \ldots \ldots \ldots \ldots \ldots \ldots \ldots$

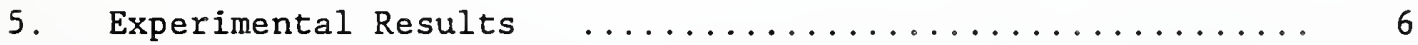

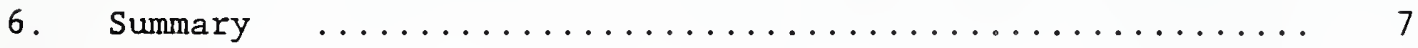

7. Acknowledgements $\ldots \ldots \ldots \ldots \ldots \ldots \ldots \ldots \ldots \ldots \ldots \ldots$

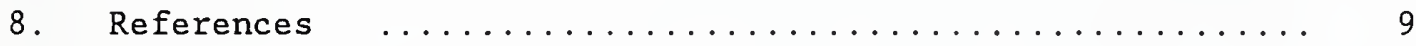

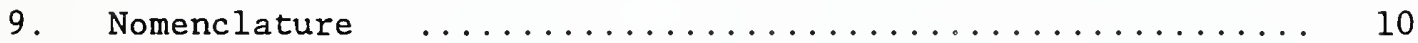

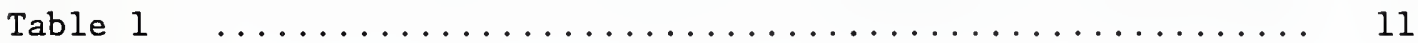

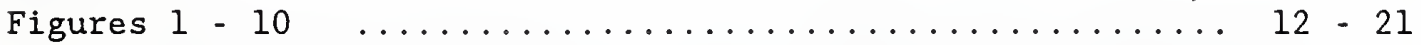

Appendix A The Mathematical Formulation of Flow of Gases Through Horizontal Ceiling Vent .... 22

Appendix B Cooper's Vent Flow Model $\ldots \ldots \ldots \ldots \ldots \ldots \ldots$

Appendix $C \quad$ Calculation of the Differential Pressure Across the Ceiling Vent $\ldots \ldots \ldots \ldots \ldots \ldots \ldots 28$ 
List of Tables

Table 1. Top Vented Compartment Fire Experimental Data

List of Figures

Figure 1. The Compartment Fire Test Apparatus

Figure 2. The Compartment Fire Liquid Fuel System

Figure 3. Differential Pressure - Time Trace

Compartment Fire with No Vent

Figure 4. Differential Pressure - Time Trace

Compartment Fire with 4 in Dia. Ceiling Vent

Figure 5. Fuel Mass - Time Trace

Compartment Fire with 5 in Dia. Ceiling Vent

Figure 6. Fuel Mass - Time Trace

Compartment Fire with 6 in Dia. Ceiling Vent

Figure 7. Differential Pressure - Time Trace

Compartment Fire with 5 in Dia. Ceiling Vent

Figure 8. Differential Pressure - Time Trace

Compartment Fire with 6 in Dia. Ceiling Vent

Figure 9. Fuel Mass - Time Trace

Compartment Fire with 12 in $\mathrm{x} 12$ in Square Ceiling Vent

Figure 10. Differential Pressure - Time Trace

Compartment Fire with 12 in $\times 12$ in Square Ceiling Vent 


\title{
AN EXPERIMENTAL STUDY OF TOP VENTED COMPARTMENT FIRES
}

\author{
by \\ King-Mon Tu \\ Center for Fire Research \\ National Institute of Standards and Technology \\ Gaithersburg, Maryland 20899
}

\begin{abstract}
In a top vented compartment fire, both density difference and pressure difference across the horizontal ceiling vent control the vent flow. This research work pursued experimental studies and investigations of exchange flows through a horizontal ceiling vent as related to solely top vented compartment fire situations. A cubic box with inside dimensions of $0.43 \mathrm{x}$ $0.43 \times 0.43 \mathrm{~m}$ high $(17 \times 17 \times 17$ in) and walls of $0.025 \mathrm{~m}$ ( 1 in) thick Kaowool was employed for the compartment fire tests. For compartment fires of various horizontal ceiling vent sizes: (1) the fuel mass burning rates were measured, and (2) the air and combustion-flue-gas exchange flow rates were estimated based on [i] available theories and [ii] gas concentrations in the fire compartment.
\end{abstract}

Keywords: Ceiling Vents; Compartment Fires; Density differential; Fire Models; Flow Rate; Pressure Differential; Vents 
This report contains the results of an experimental study of top vented compartment fires, i.e. fires burning in enclosed spaces with the ventilation solely from above. Such fires present an interesting challenge to fire modelers. The mass flow through the vent and the mass burning rate are dependent on the size of the vent in relation to the size of the compartment. Scenerio examples are: (1) fires in ships with deck hatches, (2) fires in buildings with stairways, opened ceiling vents or burned out skylights, and (3) fires in underground tunnels with vertical ventilation outlets, etc. Physically, in the top vented compartment fire, both the outgoing combustion gases and the incoming fresh air are flowing interactively through the horizontal ceiling vent. These exchange vent flows result from the density difference $\Delta \rho$ and pressure difference $\Delta \mathrm{p}$ across the horizontal ceiling vent. Experimental data on exchange vent flows across the horizontal ceiling vent are crucial in the mathematical modeling of top vented compartment fires.

There has been very limited theoretical/experimental work done on exchange vent flows through horizontal ceiling vents. As reviewed by Cooper [1], the standard vent flow model (Appendix B), which assumes unidirectional flow and the applicability of Bernoulli's equation across the horizontal vent, can calculate the flow rate through a top vented compartment fire. However, Cooper [1] also pointed out that this standard vent flow model will break down and a bidirectional exchange vent flow will exist in the situation where cross-vent density differences are unstable (e.g., a low density hot gas below a high density cool gas) and where cross-vent pressure differences are relatively small.

Experimental work, using water and brine as the working fluids, has been pursued to simulate the exchange vent flows of the top vented compartment fires. Epstein [2] considered the effect of varying the L/D ratio (where L is the length of the vent and $D$ is the diameter of the vent) for the special case of zero pressure difference across the horizontal vent. Based on the experimental data, he derived a dimensionless exchange volume flow rate equation in terms of the Froude number.

In the present study, a cubic box with $0.025 \mathrm{~m}$ ( 1 in) thick Kaowool walls was constructed for the top vented compartment fire experiments. The inside dimensions were $0.43 \times 0.43 \times 0.43 \mathrm{~m} \mathrm{high}(17 \times 17 \times 17 \mathrm{in})$. This reduced scale fire compartment was tested with a variety of horizontal ceiling vent sizes. These tests led to fire phenomena which spanned the range from (i) choked and then extinguished fires, to (ii) weak or strong pulsating fires, and, finally, to (iii) steady burning fires. The pulsating (oscillating) pool fire can be described by outlining its sequence of events that occurs during a typical cycle: vaporized liquid fuel and air burn in the fire compartment, combustion products flow out from the fire compartment through the horizontal ceiling vent; oxygen level decreases, the fire dies down and results in some blue flame floating around inside the fire compartment; external fresh air is drawn into the fire compartment, mixed with the vaporized liquid fuel and the fire grows up; the cycle repeats itself and the compartment fire can be sustained indefinitely. 
The major objectives of this study were: (1) to measure the fuel mass burning rate versus horizontal ceiling vent size and (2) to compare the experimentally determined mass flow rates through the horizontal ceiling vent with those calculated from the existing theories.

2. The Flow of Gases Through Horizontal Ceiling Vents

The estimations of air and flue gases exchange flow rates through horizontal ceiling vents from available theories and past salt water experiments were studied. Environments considered here were fire inside a top vented compartment with ambient spaces outside and above the compartment ceiling. Cross vent density and pressure differences resulted in the exchange of gases flows through the horizontal ceiling vent.

Appendix A demonstrates the general approach of the standard vent flow model to compute the gas flow through the horizontal ceiling vent. The model employs Bernoulli's equation with a flow contraction coefficient. The basic solution obtained was that the flow direction was solely determined by the pressure difference across the vent and was always unidirectional.

Epstein [2], by correlating test data of salt-water/fresh-water exchange flow experiments under zero cross vent pressure difference conditions, proposed four empirical expressions for the exchange flow through horizontal circular/rectangular vents for four different exchange flow regimes: (1) an oscillatory exchange flow regime, (2) a countercurrent Bernoulli flow regime, (3) a regime of combined turbulent binary diffusion and Bernoulli flow, and (4) a regime of pure turbulent binary diffusion.

Cooper [1] who recognized the anomaly of the standard vent flow model which used only the cross vent pressure difference to predict stable unidirectional flow according to Bernoulli's equation, extended Epstein's work and developed a uniformly valid general flow model. Appendix B shows Cooper's [1] calculation equation for the flow through a horizontal ceiling/floor vent under the condition that differential pressure across the horizontal vent is zero.

$$
\mathrm{V}_{\mathrm{EX}}=0.055\left(\mathrm{D}^{5} \mathrm{~g} \Delta \rho / \bar{\rho}\right)^{1 / 2} \quad\left(\mathrm{~m}^{3} / \mathrm{s}\right)
$$

Equation (1) can be used to calculate the volume exchange flow rate in terms of vent diameter and gas density data.

In order to have a comparison, an alternative approach is employed. The NBS Special Publication 722 [5], entitled "A User's Guide for RAPID, Reduction Algorithms for the Presentation of Incremental Fire Data", prorides a subroutine to calculate the total rate of heat release for a ystem based on the oxygen depletion and mass flow rate of exhaust gases through an exhaust duct or other exhaust collection device. The rate of heat release equation is 


$$
Q^{\prime}=S *\left(M\left(O_{2}\right) / M(A I R)\right) * m^{\prime} * X
$$

where,

$$
\begin{aligned}
\mathrm{Q}^{\prime} & =\text { rate of heat release, } \mathrm{kW} \\
\mathrm{S} & =\text { specific energy }(=12851 \mathrm{~kJ} / \mathrm{kg} \text { for Ethyl Alcohol) } \\
\mathrm{M}\left(\mathrm{O}_{2}\right) & =\text { molecular weight of oxygen }(=32 .) \\
\mathrm{M}(\mathrm{AIR}) & =\text { molecular weight of air }(=28.97) \\
\mathrm{m}^{\prime} & =\text { mass flow rate of gases through collection duct, } \mathrm{kg} / \mathrm{s} \\
\mathrm{X} & =1 /\left\{\left[\left(1-\mathrm{XO}_{2}-\mathrm{XCO}_{2}\right) /\left(\mathrm{XO}_{2}(0) *\left(1-\mathrm{XCO}_{2}\right)-\mathrm{XO}_{2} *\left(1-\mathrm{XCO}_{2}(0)\right)\right)\right]+(\mathrm{b}-1)\right\} \\
\mathrm{XO}_{2}(0) & =\text { baseline oxygen concentration, as a fraction } \\
\mathrm{XO}_{2}=\text { oxygen concentration, as a fraction } & \\
\mathrm{XCO}_{2}(0) & =\text { baseline carbon dioxide concentration, as a fraction } \\
\mathrm{XCO}_{2} & =\text { carbon dioxide concentration, as a fraction } \\
\mathrm{b} & =\text { stoichiometric factor, dimensionless (b = } 1.667)
\end{aligned}
$$

This equation (2) calculates $\mathrm{m}^{\prime}$ if all the other physical terms can be determined from experimental results.

The calculated mass exchange flow rates of $\rho_{B O T} V_{E X}$ from Equation ( 1 ) and $\mathrm{m}^{\prime}$ from Equation (2) are listed in Table 1 for various top vented compartment fire experiments.

\section{Experimental Facilities for the Top Vented Compartment Fires}

A reduced scale fire test compartment with inside dimensions of $0.43 \times 0.43 \mathrm{x}$ $0.43 \mathrm{~m}$ high ( $17 \times 17 \times 17$ in) was constructed of $0.025 \mathrm{~m}$ ( 1 in) thick Kaowool board. This fire test compartment was rigidly fastened on top of a metal frame to provide safe and stable mounting. Figure 1 shows the pictorial layout of the top vented compartment fire test apparatus. At the center of the front Kaowool pane1, a $0.216 \times 0.216 \mathrm{~m}(81 / 2 \times 81 / 2 \mathrm{in})$ square furnace glass (not shown in Figure 1) was installed for viewing the compartment fire. The bottom Kaowool panel had a $0.108 \mathrm{~m}$ (4 1/4 in) diameter opening at its center where the liquid fuel pan (a copper reducing coupling with inside diameter of $0.106 \mathrm{~m}$ ( $43 / 16 \mathrm{in})$ ) was situated with its periphery protruding about $0.003 \mathrm{~m}$ ( $1 / 8 \mathrm{in}$ ) above the Kaowool floor. The liquid fuel pan was part of the fuel level control system (a copper piping assembly) which was designed to maintain a constant liquid fuel level during the compartment fire tests. There was a fuel supply container which was steadily feeding fuel into the liquid fuel level control system during the compartment fire tests. Since the fuel volume (or mass) was maintained constant inside the fuel level control system during the compartment fire tests, any fuel that was not consumed came out of the overflow and drained into the liquid fuel return collecting container. By employing a sensitive load cell to record the combined total weight of, (1) the fuel supply container and the supply fuel, (2) the fuel return collecting container and the return fuel, and (3) their supporting metal frame, the resulting weight change versus time was determined. This was differentiated to determine the mass burning rate of the fuel of the compartment fire. Figure 2 shows the setup of the liquid fuel level control system. 
Inside the fire test compartment, there were two thermocouple trees (type $\mathrm{K}$ with 2-mil wires) to measure the gas temperature versus height with respect to time. At the center of the compartment, above the fire pan, was the 9 -element thermocouple tree which measured the gas temperatures at $0.05 \mathrm{~m}$, $0.10 \mathrm{~m}, 0.15 \mathrm{~m}, 0.20 \mathrm{~m}, 0.25 \mathrm{~m}, 0.30 \mathrm{~m}, 0.35 \mathrm{~m}, 0.40 \mathrm{~m}$ above the floor and at the ceiling height. At $0.22 \mathrm{~m}$ ( $8.5 \mathrm{in}$ ) from the fire compartment front and about $0.05 \mathrm{~m}$ from the left side wall was the 5 -element thermocouple tree which measured gas temperatures at $0.05 \mathrm{~m}, 0.15 \mathrm{~m}, 0.25 \mathrm{~m}, 0.35 \mathrm{~m}$ and $0.40 \mathrm{~m}$ above the floor. There were another five thermocouples (type $\mathrm{K}$ with 5 -mil wires) for the gas temperature measurements at the ceiling vent location: one of them was at the center of the ceiling vent and the other four were uniformly distributed near the edge and around circumference of the ceiling vent.

Differential pressure across the horizontal ceiling vent and differential pressure between inside and outside of the fire compartment at floor level were monitored during the course of the compartment fire tests. (see Appendix $C$ for calculation of differential pressure across the ceiling vent.) Oxygen, carbon dioxide and carbon monoxide gas volume concentrations, at $0.076 \mathrm{~m}$ ( 3 in) away from the center of the fire compartment back wall right below the ceiling level, were monitored by a gas sampling probe during the compartment fire tests. Water was trapped ahead of the gas analyzers. Carbon dioxide was not trapped ahead of the oxygen analyzer. Tests were repeated with the gas sampling probe relocated at an elevation of $0.025 \mathrm{~m}$ ( 1 in) above the floor level.

Test data of one load cell fuel mass output, three gas volume concentration outputs and nineteen-thermocouple gas temperature outputs were recorded on a 5-1/4 inch floppy disk once every two seconds by an IBM PC/XT data acquisition system. Data plotting routines were used to present the test data in graphical form. A video camera was also used to provide a visual recording of some of the compartment fire tests.

The liquid fuel employed for the series of compartment fire tests was Ethanol (200 proof anhydrous pure Ethyl Alcohol, U.S.P. $\mathrm{C}_{2} \mathrm{H}_{5} \mathrm{OH}$ ): a pure chemical with lower heat of combustion of $26820 \mathrm{~kJ} / \mathrm{kg}$ and density of $794 \mathrm{~kg} / \mathrm{m}^{3}$.

The horizontal ceiling vents employed for the top vented compartment fire experiments were: (1) zero opening (no vent) or vent diameters less than 0.089 $\mathrm{m}$ (3.5 in), (2) $0.102 \mathrm{~m}$ (4 in) diameter, (3) $0.127 \mathrm{~m}$ (5 in) diameter, (4) $0.152 \mathrm{~m}$ ( $6 \mathrm{in}$ ) diameter and (5) $0.305 \times 0.305 \mathrm{~m}(12 \times 12 \mathrm{in})$ square vent. The thickness of the ceiling was $0.038 \mathrm{~m}(1.5 \mathrm{in})$ for all the circular vents and $0.025 \mathrm{~m}$ ( $1 \mathrm{in}$ ) for the square vent.

4. The Compartment Fire Test Procedure

To carry out a compartment fire test, the first step was to fill up the liquid fuel level control system with Ethanol to the appropriate level. The next step was to allow the liquid fuel supply container to start feeding Ethanol 
into the liquid fuel level control system with any overflow continuously draining into the liquid fuel return collecting container. The front compartment panel was then closed and locked. The data acquisition system which recorded data once every two seconds, and the resistance type electric igniter inside the fire compartment were turned on and the fire was initiated within a few seconds. After the liquid fuel ignited, the electric igniter was turned off. Tests usually ran for one hour.

5. Experimental Results

Top Vented Compartment Fires with no Vent or vent diameters less than $0.089 \mathrm{~m}$ (3.5 in)

With no vent or with vent diameters less than $0.089 \mathrm{~m}$ ( $3.5 \mathrm{in}$ ), the pool fires were choked and went out within two minutes. Figure 3 shows the differential pressures across the ceiling vent and at the floor level for the compartment fire test with no vent. The spikes of the differential pressures at the time of ignition were due to gas thermal expansion within the sealed fire compartment. As thermal energy was absorbed by the fire compartment walls, the differential pressures were gradually equilibrated back to their initial, prior to fire, values. At the time that the fire was extinguished due to short of oxygen supply, as a mirror image effect, the differential pressures made dips and then descended. At the moment of fire extinction (about one minute after the ignition), the oxygen volume fraction was about 15.5\%, carbon dioxide about $3.5 \%$ and carbon monoxide about $0.06 \%$. Fuel mass burning rates were too small to be measured by the load cell.

Table 1 presents the relevant top vented compartment fire test data for vents $0.102 \mathrm{~m}$ (4 in) diameter and greater.

Top Vented Compartment Fires with $0.102 \mathrm{~m}$ (4 in) Dia. Horizontal Ceiling Vent

The 4 in diameter vent resulted in a very weak pulsating fire which went out in about 5.5 minutes. Fire patterns were erratic and no approximate frequency can be observed. The fuel mass burning rate was estimated to be about 0.091 $\mathrm{kg} / \mathrm{hr}$ by comparing the initial and final weights of the liquid fuel. Figure 4 shows the differential pressures across the ceiling vent and at the floor level. Oxygen volume fraction at ceiling level went down to about $15.5 \%$ prior to fire extinction.

Top Vented Compartment Fires with $0.127 \mathrm{~m}$ (5 in) Dia. and $0.152 \mathrm{~m}$ ( 6 in) Dia. Horizontal Ceiling Vents

These tests resulted in stronger pulsating pool fires which were intentionally terminated after one hour testing period. The fire patterns were still very irregular and no approximate frequency can be determined. From the fuel mass 
- time traces (Figures 5 and 6), the fuel mass burning rates were estimated to be $0.22 \mathrm{~kg} / \mathrm{hr}$ and $0.27 \mathrm{~kg} / \mathrm{hr}$ for the ceiling vents of $0.127 \mathrm{~m} \mathrm{Dia}$, and $0.152 \mathrm{~m}$ Dia. respectively. Likewise, differential pressures across the ceiling vent and at the floor level are shown in Figure 7 for $0.127 \mathrm{~m} \mathrm{Dia}$. vent and in Figure 8 for $0.152 \mathrm{~m}$ Dia. vent.

Top Vented Compartment Fires with $0.305 \times 0.305 \mathrm{~m}$ (12 x 12 in) Square Horizontal ceiling Vent

This vent resulted in a strong steady pool fire. The fuel mass burning rate was estimated to be $0.5 \mathrm{~kg} / \mathrm{hr}$ from the fuel mass - time trace (Figure 9), the highest for the series of compartment fire tests as was expected since this was the largest vent. Despite the large opening the differential pressures (Figure 10) indicated a below-atmosphere pressure in the compartment immediately below the elevation of the ceiling vent. The oxygen and carbon dioxide volume fractions were close to atmospheric and carbon monoxide volume fraction values were very low.

The measured compartment fire differential pressures across the horizontal ceiling vent were in the range of 0.1 to 0.3 Pascal (Appendix C and Table 1), the same order of magnitude as under none fire conditions. Assuming a zero cross-vent pressure difference, numerical calculations of the mass flow rate of gases through the horizontal ceiling vent were carried out using equation (1). Air was considered as a perfect gas and the perfect gas law was applied to relate the pressure, density and temperature. The reference density of air (at $293 \mathrm{~K}$ or $20 \mathrm{C}$ ) applied was $1.202 \mathrm{~kg} / \mathrm{m}^{3}(0.0751 \mathrm{bm}$ per cubic foot). The compartment volume was about $0.8 \mathrm{~m}^{3}\left(2.8 \mathrm{ft}^{3}\right)$ and the compartment air mass was estimated to be about $0.1 \mathrm{~kg}(0.21 \mathrm{lbm})$. Using experimental data obtained from the current top vented compartment fire tests, equation (2) was also used to calculate the mass flow rate.

Mass burning rates for the various vent sizes are listed in Table 1 . Results from the calculation of both equations (1) and (2) are also listed in Table 1. The calculated exchange flow rate $Q_{1}$ from equation ( 1 ) is always higher than the experimentally determined exchange flow rate $Q_{2}$ from equation (2). The values of $Q_{1}$ and $Q_{2}$ are within reasonable physical range for vent diameters of $0.102 \mathrm{~m}$ (4 in), $0.127 \mathrm{~m} \mathrm{(5} \mathrm{in)} \mathrm{and} 0.152 \mathrm{~m}$ ( $6 \mathrm{in}$ ) but are unacceptably high for the $0.305 \times 0.305 \mathrm{~m}(12 \times 12 \mathrm{in})$ square vent situation.

6. Summary

(1) A reduced scale fire compartment was constructed to study top vented compartment fires. Depending on the various horizontal ceiling vent sizes, the liquid fuel compartment fires may range from (i) choked and then extinguished pool fires to (ii) erratic pulsating pool fires and finally to (iii) strong steady pool fires. 
(2) Liquid fuel mass burning rates were measured by a load cell during the compartment fire tests.

(3) Differential pressures across the ceiling vent were measured experimentally during the compartment fire tests and were found to be of the same order of magnitude as before the fire tests (Appendix $C$ and Table 1). Therefore, a zero pressure difference across the horizontal ceiling vent for the compartment fire is physically an acceptable assumption and the exchange vent flow correlation (Equation 1) as was suggested by Cooper [1] or Epstein [2] can be utilized. The results are listed in Table 1 .

(4) The rate of heat release equation in RAPID (Equation 2) was also applied to calculate the exchange vent flow and results are in general compatible with Cooper's or Epstein's correlation (see Table 1).

(5) From the differential pressure data across the horizontal ceiling vent, it is concluded that the fresh air and combustion flue gases flowed in and out simultaneously each through part of the horizontal ceiling vent.

(6) Of all the compartment fire tests, liquid fuel mass - time plots (Figures 5,6 , and 9) all show some fairly constant slopes. In other words, the 1iquid fuel mass burning rates were different for compartment fire tests of different vent sizes, but the liquid fuel mass burning rate was fairly constant for a given vent size even though the compartment ceiling level gas temperatures (Figures 5, 6, and 9) were increasing during the test period of the compartment fire.

(7) In the fire compartment, pulsating pool fires were visually observed under some particular "ventilation limited" conditions. However, liquid fuel mass burning rates and differential pressure test data did not show obvious evidence of such a erratic pulsating phenomenon. Much more research work is needed in order to determine the physical conditions that control this kind of complicated in and out vent flow phenomena.

In summary, some aspects of the pulsating pool fire with ventilation solely from above using a reduced scale fire compartment were experimentally studied. The effort made was limited and preliminary. A larger scale model and more extended effort should be considered for future study of this fire phenomenon.

\section{Acknowledgements}

Dr. W. Parker and Dr. J. Quintiere collaborated in the project at several stages. Mr. D. Lowe prepared the data collection and analysis routines. 
[1] Cooper, L.Y., Calculation of the Flow Through a Horizontal Ceiling/Floor Vent, NBSIR 89-4052, National Bureau of Standards, Gaithersburg, MD, 1989.

[2] Epstein, M., Buoyancy-Driven Exchange Flow Through Small Openings in Horizontal Partitions, J. Heat Transfer, 110, pp. 885-893, 1988.

[3] Emmons, H., Vent Flows, Section 1, Chapter 8, SFPE Handbook of Fire Protection Engineering, SFPE, Boston, pp. 130-138, 1988.

[4] Cannon, J.B. and Zukoski, E.E., Turbulent Mixing in Vertical Shafts under Conditions Applicable to Fires in High Rise Buildings, Technical Report No. 1, National Science Foundation Grant No. GI 31892 X, 1976.

[5] Breese, J.N. and Peacock, R.D., A User's Guide for RAPID, Reduction Algorithms for the Presentation of Incremental Fire Data, NBS Special Publication 722, National Bureau of Standards, Gaithersburg, MD, 1986.

[6] Parker, W.J., Calculation of the Heat Release Rate by Oxygen Consumption for Various Application, NBSIR 81-2427-1, National Bureau of Standards, Gaithersburg, MD, 1982.

[7] Brown, W.G., Natural Convection Through Rectangular Openings in Partitions - 2. Horizontal Partitions, Int. J. Mass Transfer, 5, pp. $869-878,1962$.

[8] Porter, J.W., Pulsating Combustion of Liquid Fuel in Partially Closed Vessels, Department of Aerospace Engineering, University of Texas, Austin, Texas, 1967.

[9] Mercer, A. and Thompson, H., An Experimental Investigation of some Further Aspects of the Buoyancy-Driven Exchange Flow Between Carbon Dioxide and Air Following a Depressureization Accident in a Magnox Reactor, Part I: The Exchange Flow in Inclined Ducts, J. Br. Nucl. Energy Soc., 14, pp. 327-334, 1975.

[10] Mercer, A, and Thompson, H., An Experimental Investigation of Some Further Aspects of the Buoyancy-Driven Exchange Flow Between Carbon Dioxide and Air Following a Depressurization Accident in a Magnox Reactor, Part ii: The Purging Flow Requirements in Inclined Ducts, J. Br. Nucl. Soc., 14, pp. 335-340, 1975.

[11] Takeda, H., Oscillatory Phenomenon and Inverse Temperature Profile Appearing in Compartment Fires, Combustion and Flame 61, pp. 103-105, 1985.

[12] Takeda, H. and Akita, K., Critical Phenomenon in Compartment Fires with Liquid Fuels, Eighteenth Symposium (International) on Combustion, The combustion Institute, 1981. 
[13] Epstein, M. and M.A. Kenton, "Combined Natural Convection and Forced Flow Through Small Openings in a Horizontal Partition, with Special Reference to Flows in Multicompartment Enclosures," J. Heat Transfer, $111,980-987$ (1989).

9. Nomenclature

Av
$\mathrm{C}_{\mathrm{D}}$
$\mathrm{D}$
$\mathrm{h}, \mathrm{P}_{\mathrm{BOT}}, \mathrm{P}_{\mathrm{TOP}}$
$\mathrm{DP}$
$\mathrm{Q}$
$\mathrm{v}$
$\mathrm{V}_{\mathrm{Xx}}$
$\rho, \rho_{\mathrm{BOT}}, \rho_{\mathrm{TOP}}$
$\bar{\rho}$

Vent Area

Vent Flow Coefficient

Vent Diameter (Equation 1)

Acceleration of Gravity

Length of Height

Gas Pressure, Gas Pressure Below Ceiling Plate, Gas Pressure Above Ceiling Plate (Appendixes B and C)

Differential Pressure (Appendix C)

Mass Exchange Flow Rate (Table 1)

Gas Velocity

Volume Exchange Flow Rate (Equation 1)

Gas Density, Gas Density Below Ceiling Plate, Gas Density Above Ceiling Plate (Appendixes B and C)

Gas Density Differential (Equation 2, Appendix B) Average Gas Density (Equation 9, Appendix B) 
Table 1. Top Vented Compartment Fire Experimental Data

\begin{tabular}{|c|c|c|c|c|}
\hline Vent Diameter (D) & $\begin{array}{l}0.1016 \mathrm{~m} \\
(4 \mathrm{in})\end{array}$ & $\begin{array}{l}0.1270 \mathrm{~m} \\
(5 \mathrm{in})\end{array}$ & $\begin{array}{l}0.1524 \mathrm{~m} \\
(6 \mathrm{in})\end{array}$ & $\begin{array}{l}0.3048 \mathrm{~m}^{(*)} \\
(12 \mathrm{in})\end{array}$ \\
\hline Vent Area (A) & $\begin{array}{l}0.0081 \mathrm{~m}^{2} \\
\left(12.6 \mathrm{in}^{2}\right)\end{array}$ & $\begin{array}{l}0.0127 \mathrm{~m}^{2} \\
\left(19.6 \mathrm{in}^{2}\right)\end{array}$ & $\begin{array}{l}0.0182 \mathrm{~m}^{2} \\
\left(28.3 \mathrm{in}^{2}\right)\end{array}$ & $\begin{array}{l}0.0929 \mathrm{~m}^{2} \\
\left(144 \mathrm{in}^{2}\right)\end{array}$ \\
\hline Vent Length (L) & $\begin{array}{l}0.0381 \mathrm{~m} \\
(1.5 \mathrm{in})\end{array}$ & $\begin{array}{l}0.0381 \mathrm{~m} \\
(1.5 \mathrm{in})\end{array}$ & $\begin{array}{l}0.0381 \mathrm{~m} \\
(1.5 \mathrm{in})\end{array}$ & $\begin{array}{l}0.0254 \mathrm{~m} \\
(1 \text { in) }\end{array}$ \\
\hline $\mathrm{L} / \mathrm{D}$ & 0.375 & 0.3 & 0.25 & 0.083 \\
\hline $\begin{array}{l}\text { Differential } \\
\text { Pressure across } \\
\text { the Ceiling Vent }\end{array}$ & -0.333 Pascal & -0.267 Pascal & -0.133 Pascal & -0.2 Pascal \\
\hline $\begin{array}{l}\text { Oxygen } \\
\text { (Volume Fraction) }\end{array}$ & 15.58 & 13.58 & 13.58 & $20.4 \frac{8}{3}$ \\
\hline $\begin{array}{l}\text { Carbon Dioxide } \\
\text { (Volume Fraction) }\end{array}$ & 3.58 & 5.08 & 5.08 & 0.368 \\
\hline $\begin{array}{l}\text { Carbon Monoxide } \\
\text { (Volume Fraction) }\end{array}$ & 0.088 & 0.118 & 0.138 & 0.0158 \\
\hline $\begin{array}{l}\text { Air Temperature } \\
\text { at Ceiling Level }\end{array}$ & $600 \mathrm{~K}$ & $625 \mathrm{~K}$ & $675 \mathrm{~K}$ & $450 \mathrm{~K}$ \\
\hline $\begin{array}{l}\text { Air Density } \\
\text { at Ceiling Level }\end{array}$ & $\begin{array}{l}0.586 \\
\mathrm{~kg} / \mathrm{m}^{3}\end{array}$ & $\begin{array}{l}0.561 \\
\mathrm{~kg} / \mathrm{m}^{3}\end{array}$ & $\begin{array}{l}0.523 \\
\mathrm{~kg} / \mathrm{m}^{3}\end{array}$ & $\begin{array}{l}0.784 \\
\mathrm{~kg} / \mathrm{m}^{3}\end{array}$ \\
\hline $\begin{array}{l}\text { Mass Burning Rate } \\
\left(\mathrm{m}^{\prime}\right)\end{array}$ & $\begin{array}{c}0.09 \mathrm{~kg} / \mathrm{hr} \\
(0.2 \mathrm{lbm} / \mathrm{hr})\end{array}$ & $\begin{array}{cl}0.22 \mathrm{~kg} / \mathrm{hr} \\
(0.48 \mathrm{lbm} / \mathrm{hr})\end{array}$ & $\begin{array}{c}0.27 \mathrm{~kg} / \mathrm{hr} \\
(0.6 \mathrm{lbm} / \mathrm{hr})\end{array}$ & $\begin{array}{c}0.5 \mathrm{~kg} / \mathrm{hr} \\
(1.1 \mathrm{lbm} / \mathrm{hr})\end{array}$ \\
\hline
\end{tabular}

Exchange Flow Rate

$\begin{array}{llllll}\mathrm{Q}_{1} & 2.54 \mathrm{~kg} / \mathrm{hr} & 3.91 \mathrm{~kg} / \mathrm{hr} & 5.45 \mathrm{~kg} / \mathrm{hr} & 30.47 \mathrm{~kg} / \mathrm{hr} \\ \mathrm{Q}_{2} & 3.06 \mathrm{~kg} / \mathrm{hr} & 5.46 \mathrm{~kg} / \mathrm{hr} & 6.48 \mathrm{~kg} / \mathrm{hr} & 85.32 \mathrm{~kg} / \mathrm{hr} \\ \mathrm{Q}_{1} / \mathrm{Q}_{2} & 0.83 & 0.72 & & 0.84 & 0.36\end{array}$

Note:

$\mathrm{Q}_{1}$ is $\rho_{\mathrm{BOT}} \mathrm{V}_{\mathrm{EX}}$ in Equation (1) with $\rho_{\mathrm{BOT}}$ estimated from ceiling level air

$\mathrm{Q}_{2}$ is $\mathrm{m}^{\prime}$ in Equation (2) with gases data at ceiling level.

temperature.

(*) Square Vent $\ldots 0.3048 \mathrm{~m} \times 0.3048 \mathrm{~m}$ (12 in $x 12$ in)

$\begin{array}{lllll}\text { Common Pressure Units } & 1 \text { Pascal } & =1 \mathrm{Newton} / \mathrm{m}^{2} & & \\ & 1 \mathrm{~atm} & = & & \\ & 1 \mathrm{~mm} \mathrm{Hg} & =1 \mathrm{~mm} \mathrm{Hg} & =1.01325 \times 10^{5} \text { Pascal } \\ & 1 \mathrm{~mm} & =133.322 & \text { Pascal }\end{array}$ 


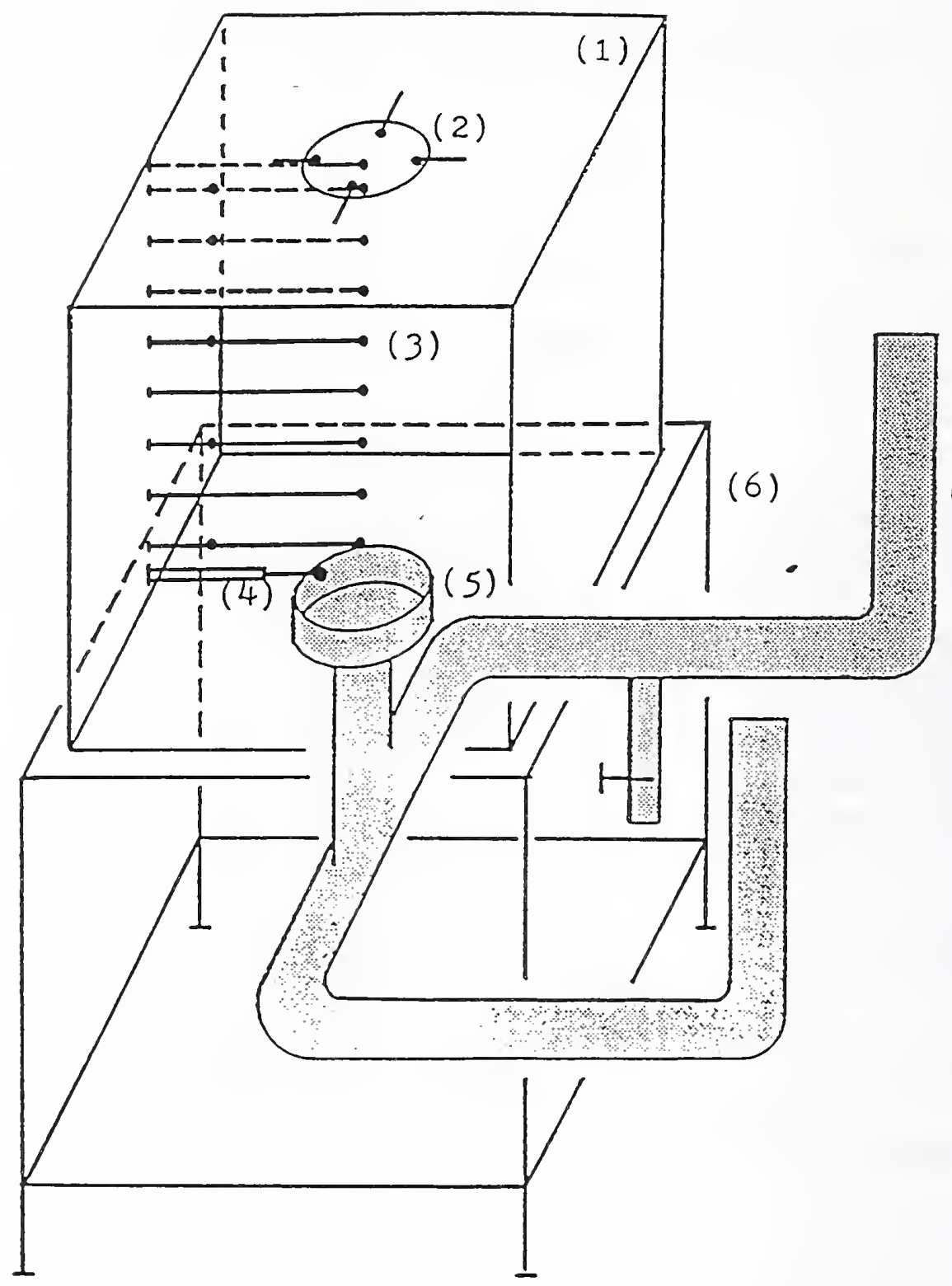

(?)

(1) Fire Test Compartment

(2) Ceiling Vent

(3) Thermocouple Trees

(4) Electric Igniter

(5) Liquid Fire Pan

(6) Support Frame

(7) Liquid Fuel Level Control System

Figure 1. The Compartment Fire Test Apparatus 


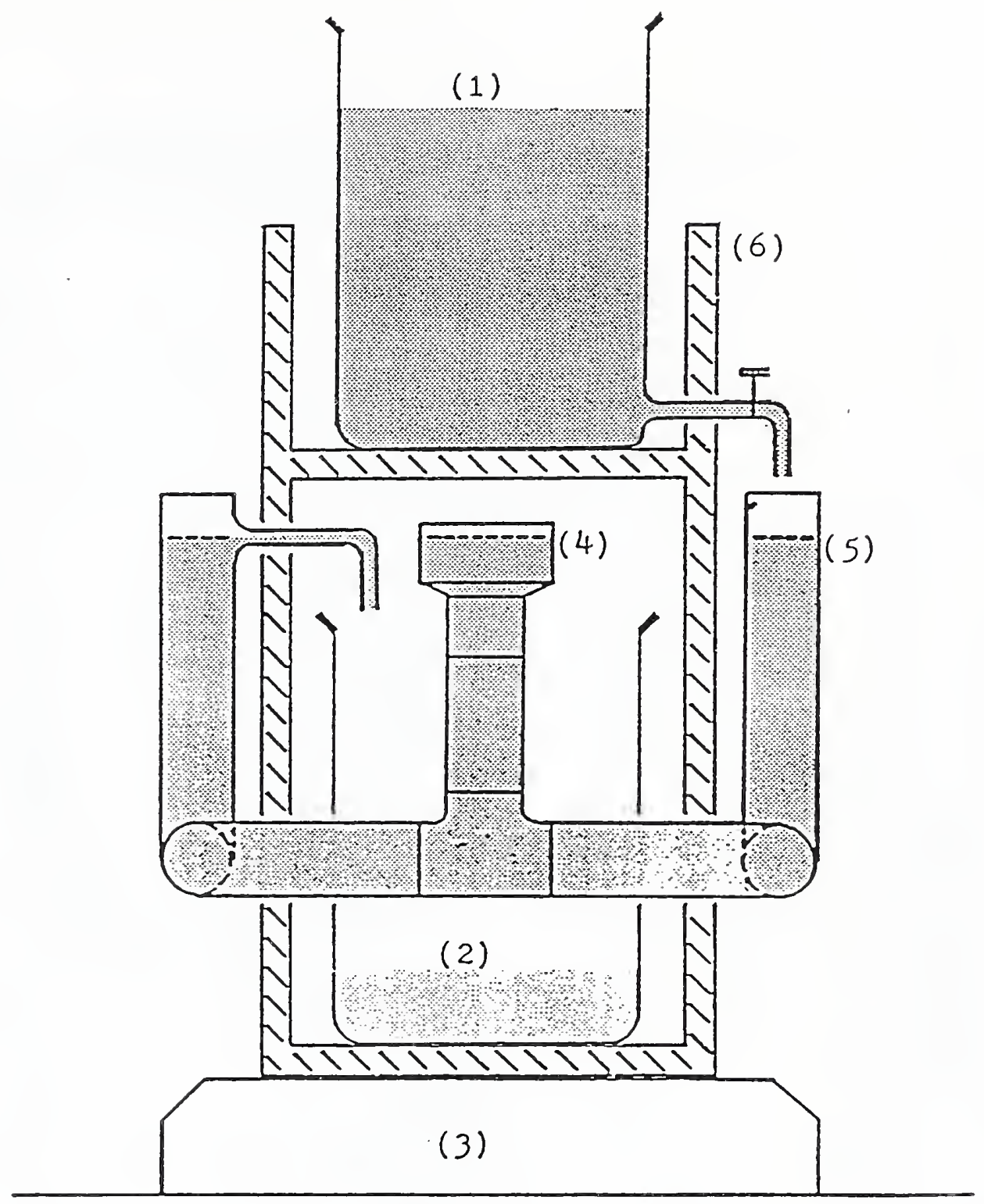

(1) Liquid Fuel Supply Container

(2) Liquid Fuel Return Container

(3) Load Cell

(4) Liquid Fire Pan

(5) Liquid Fuel Level Control System

(6) Liquid Fuel Container Support Frame

Figure 2. The Compartment Fire Liquid Fuel System 


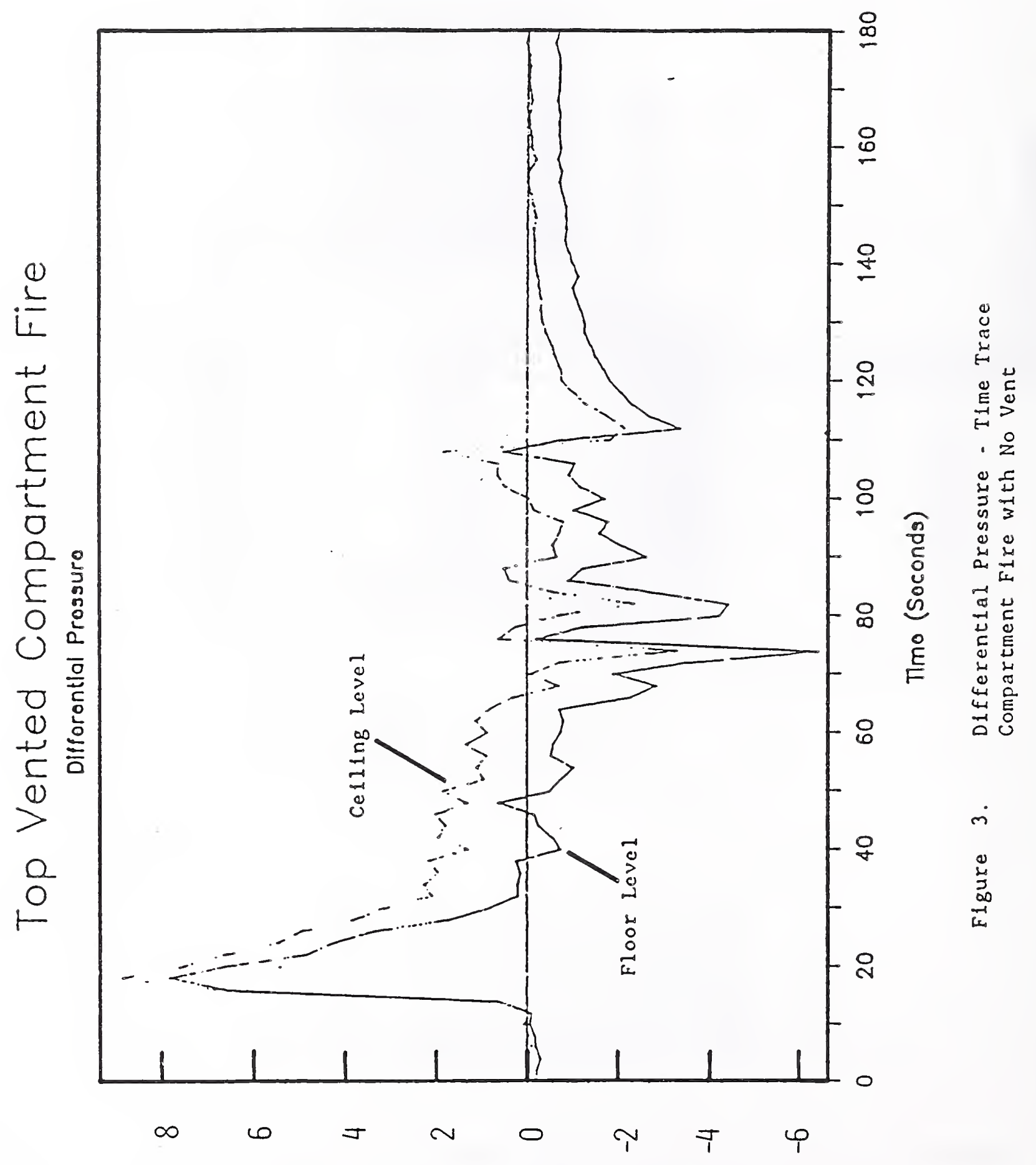

(teosed) axnssaxd tețuaxafjta 


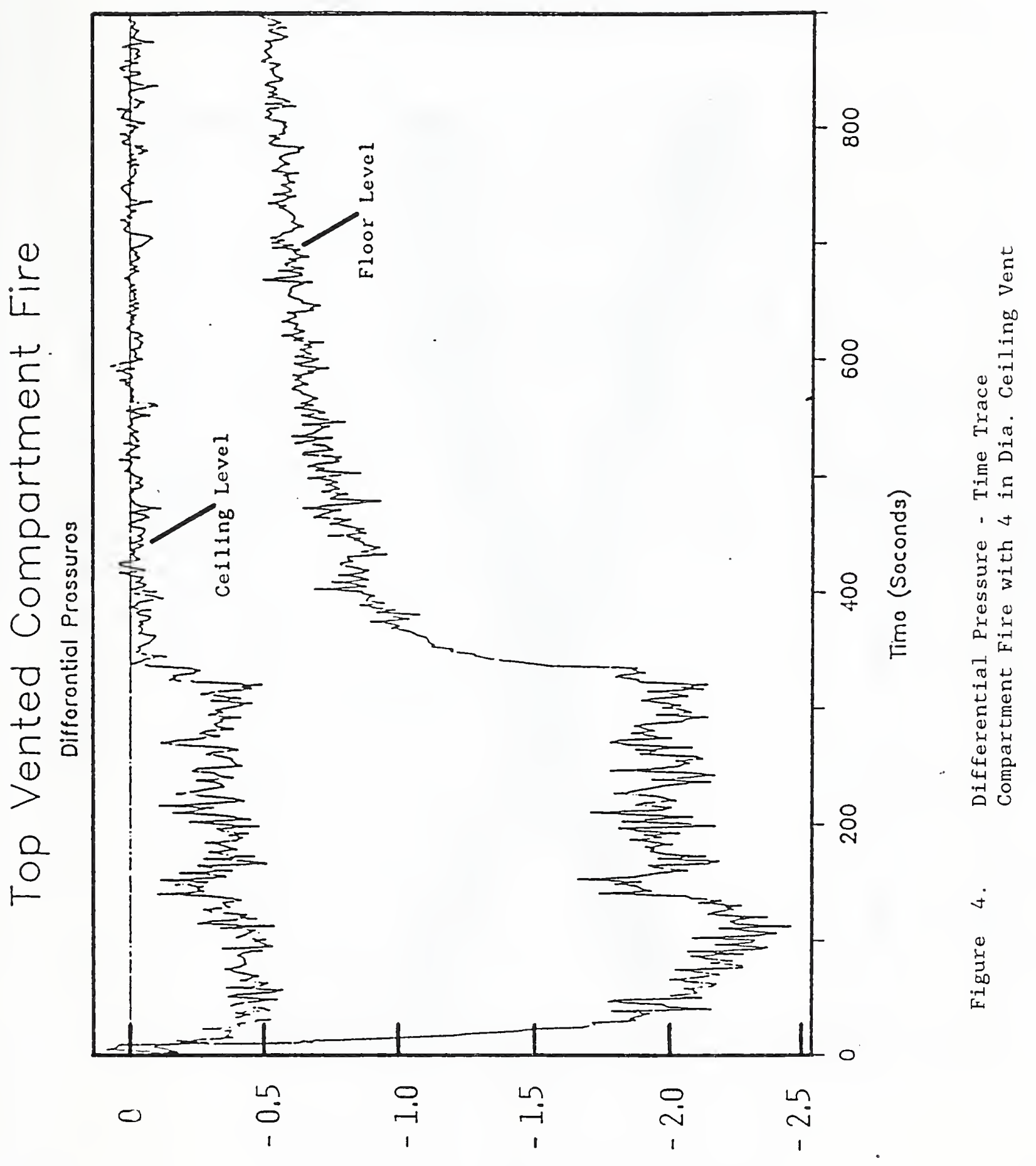

(teosed) axnsazid tetjuajafjta 


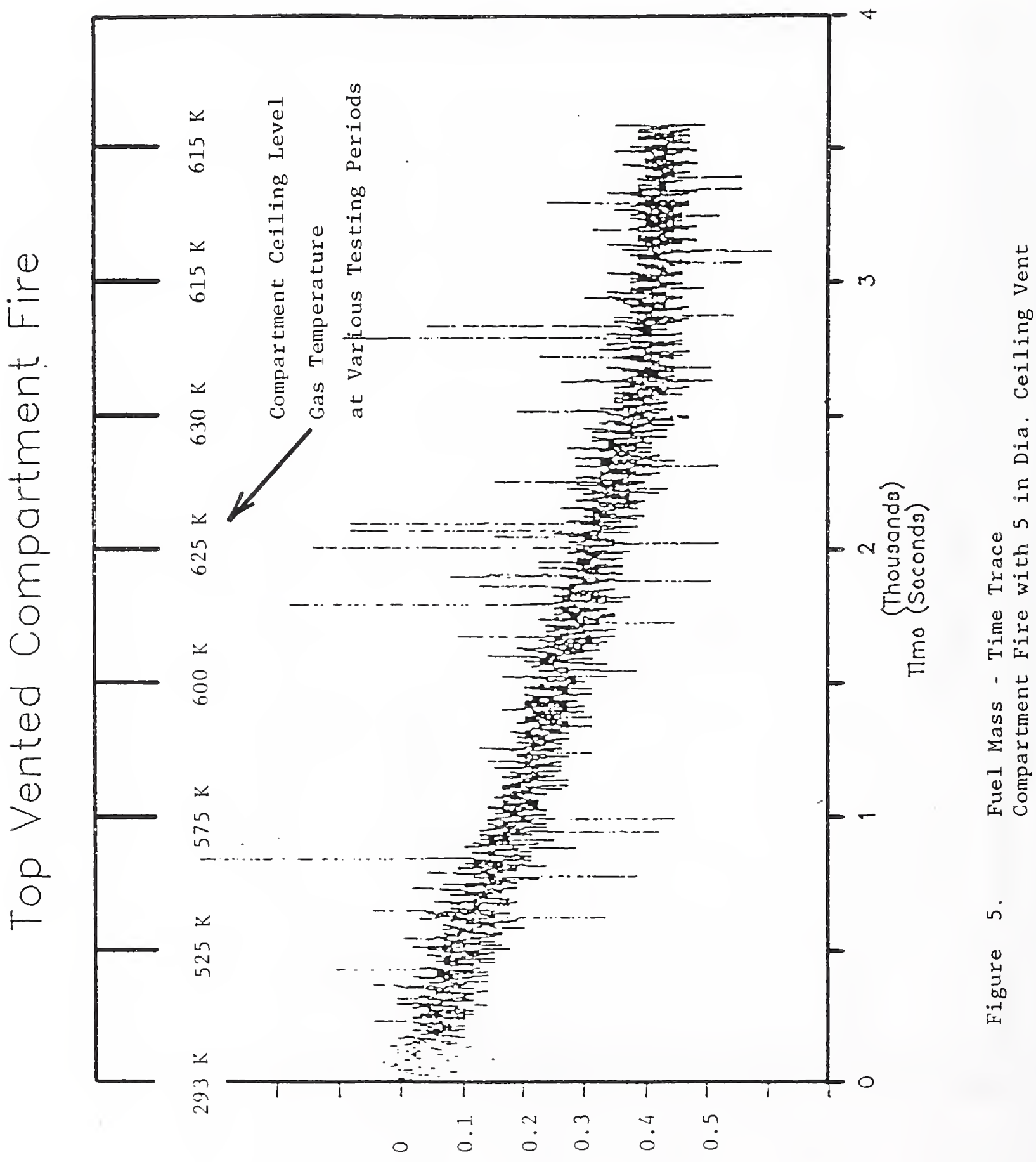

(spunoa) ssot ssew 


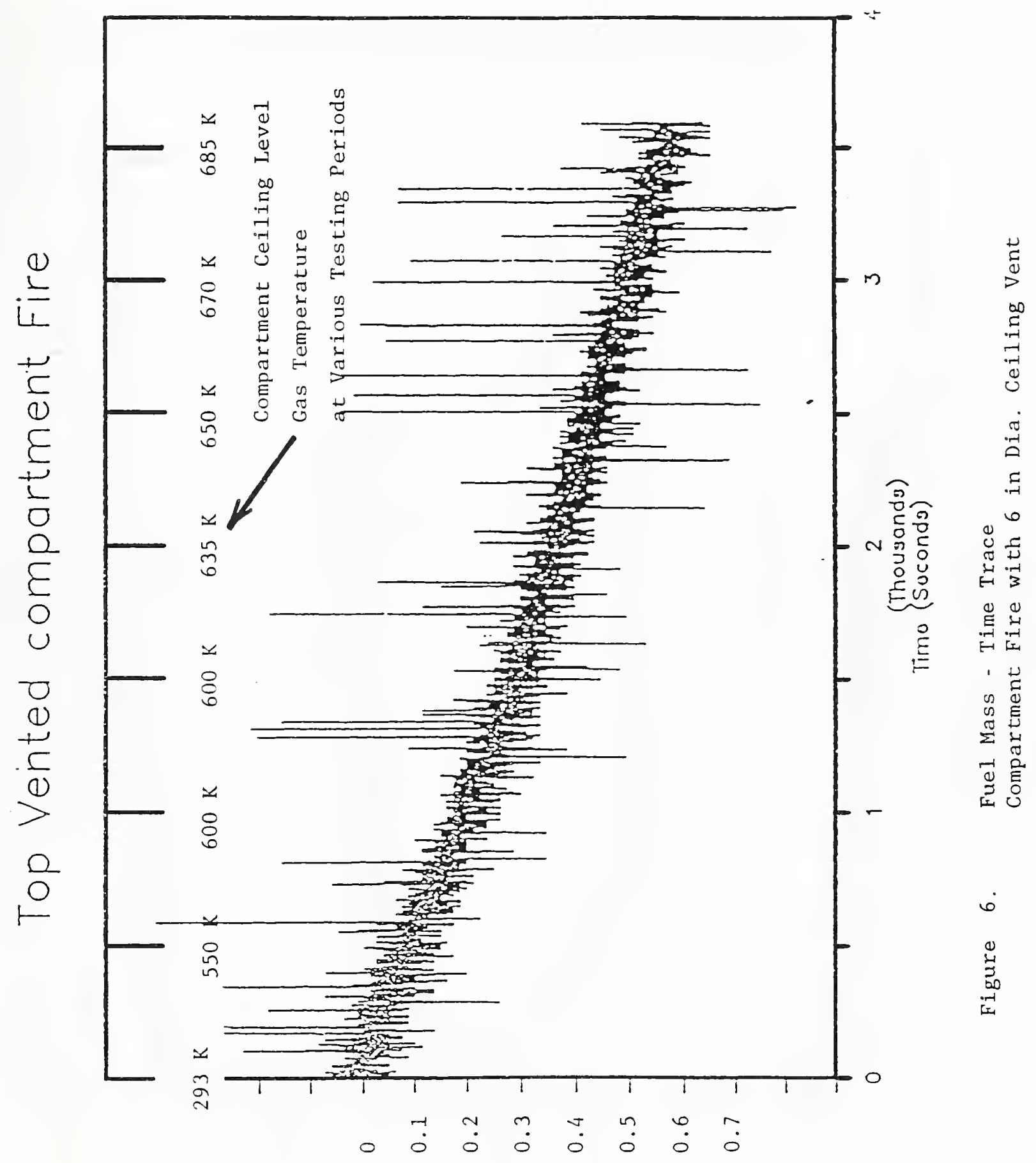

(spunod) ssot ssew 


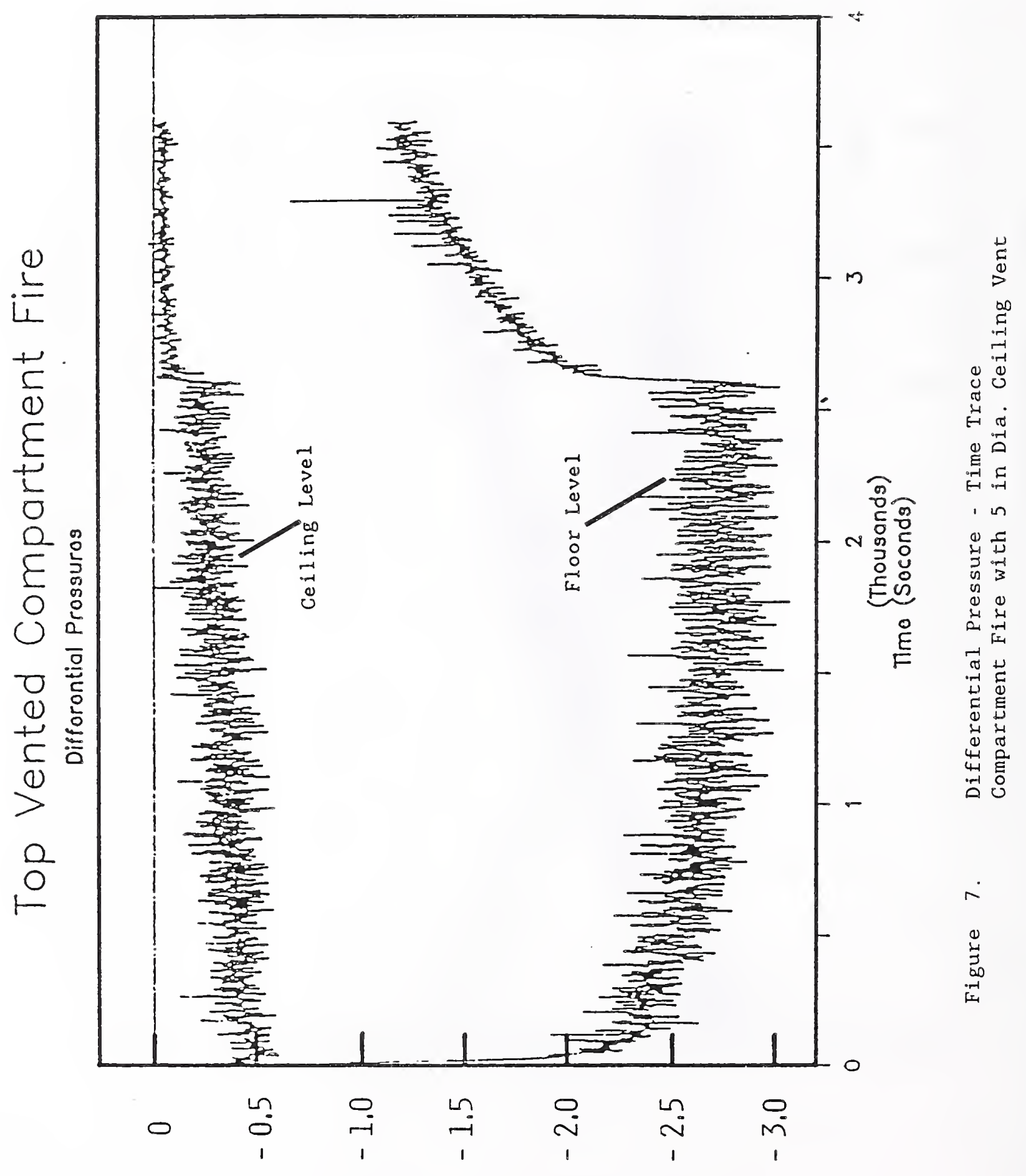

(teased) axnsarid tetiuajajita 


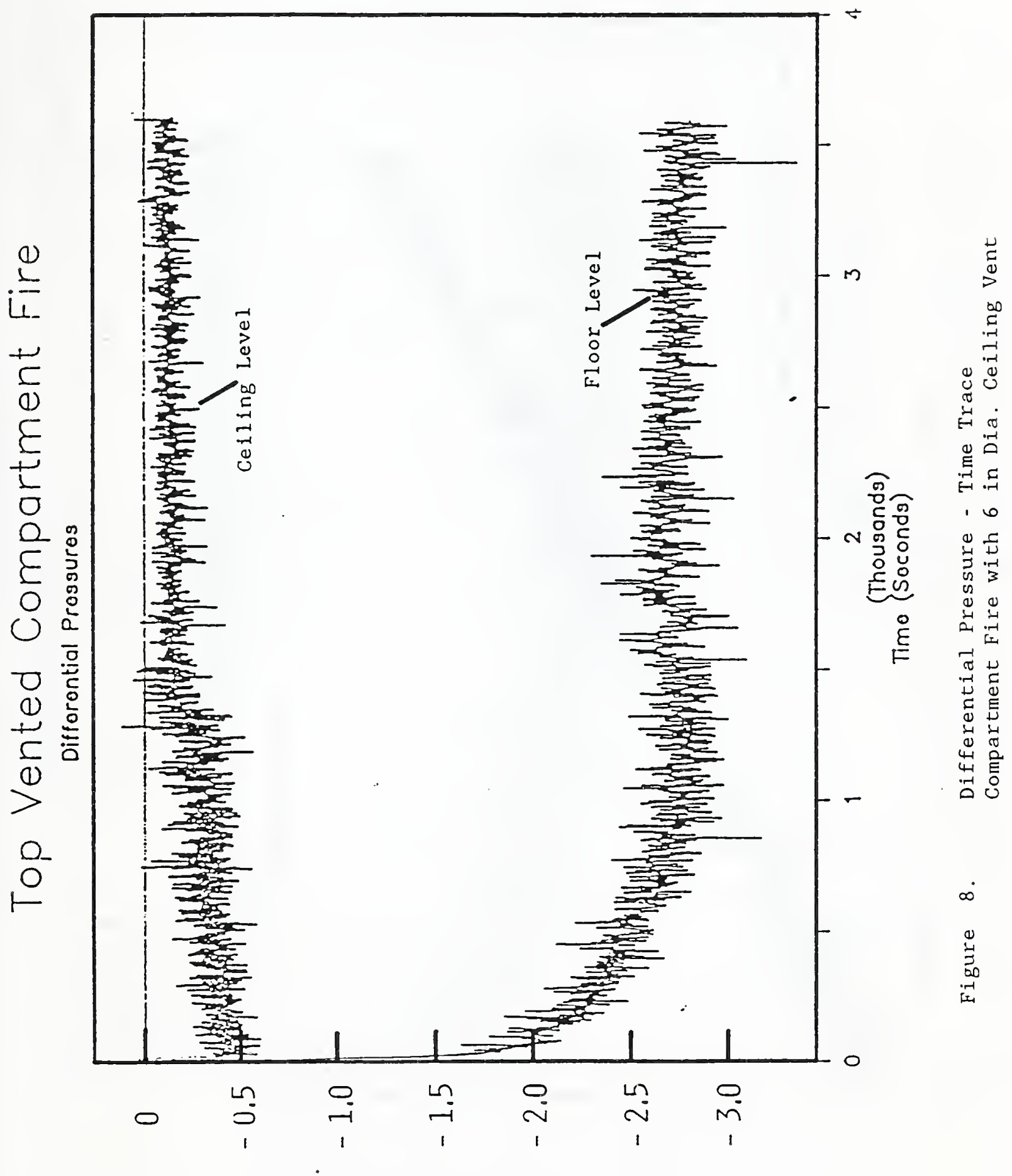

(teosed) axnssadd tețuajajita 


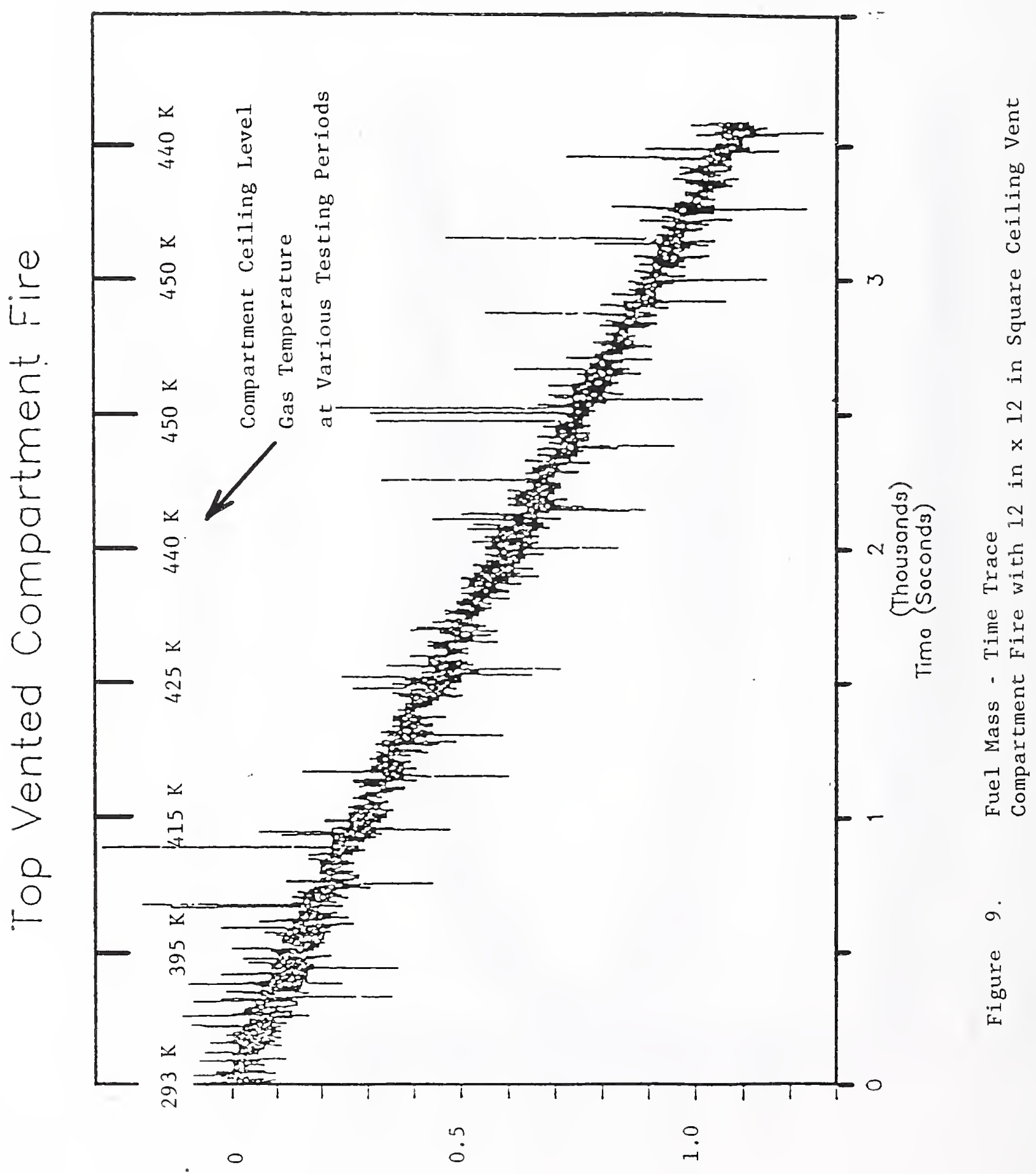

(spunod) ssot ssew 


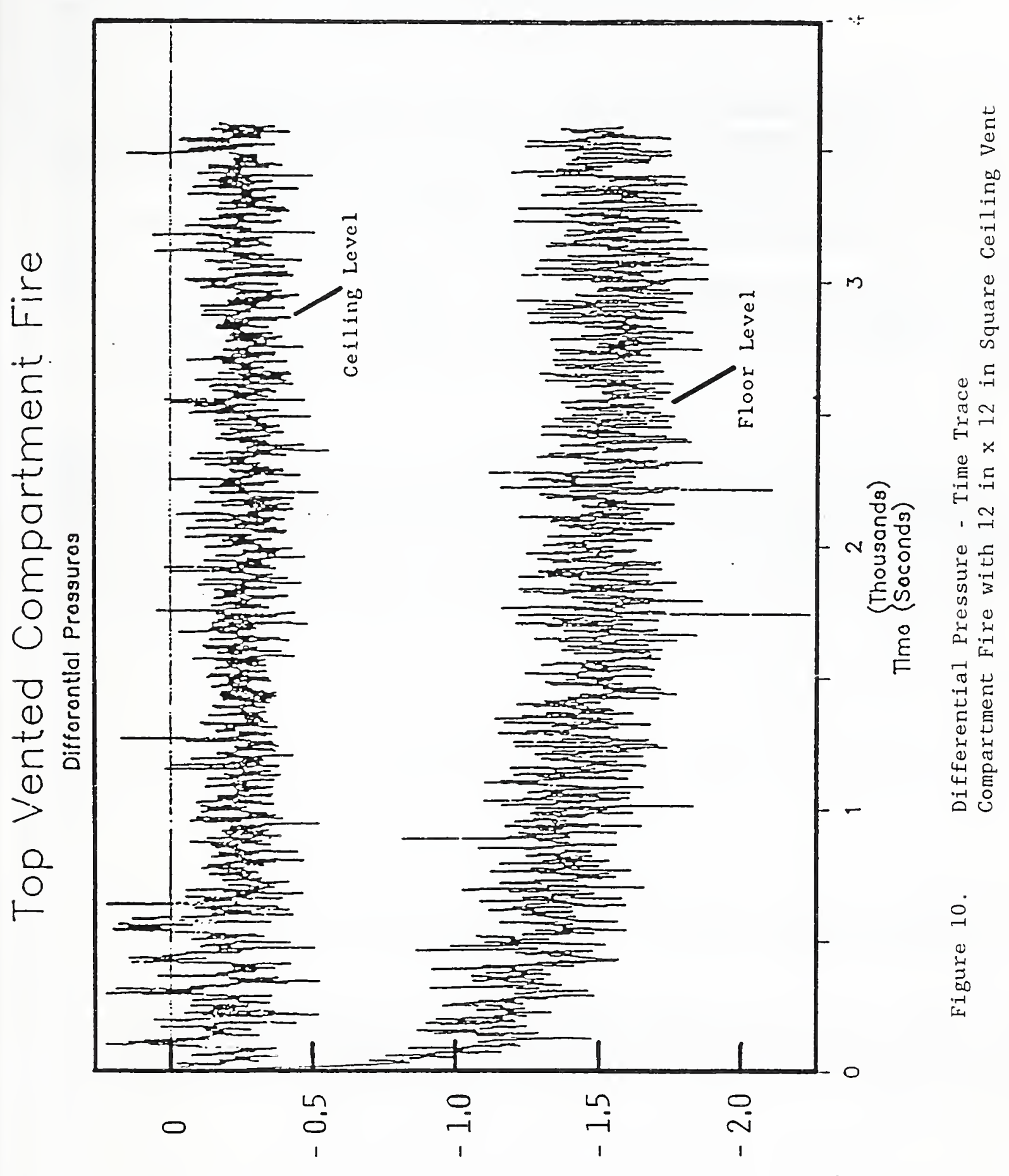

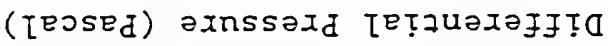


Appendix A The Mathematical Formulation

of Flow of Gases Through Horizontal Ceiling Vent

It was experimentally observed [3] that in a top vented compartment fire the flows of the outgoing combustion gas and the incoming fresh air were either both in and out simultaneously each through part of the ceiling vent area or both followed a time dependent in-out pulsating flow pattern. Due to the complex nature of this kind of fire phenomenon, mathematical formulation governing the flow of gases through ceiling vent has not been widely studied. Emmons [3] has suggested the method of hydraulics for its solution.

Consider one way outflow through the ceiling vent, Figure A-1. Apply the Bernoulli's equation along the streamline between points 1 and $A$ which is at the Vena Contracta level and is at a distance $h$ above the ceiling vent (the datum level)

$$
\mathrm{P}_{1}=\mathrm{P}_{\mathrm{A}}+\rho_{\mathrm{H}} \mathrm{gh}+1 / 2 \rho_{\mathrm{H}} \mathrm{v}_{\mathrm{H}}^{2}
$$

Apply the Bernoulli's equation between points 2 and $A^{\prime}$ outside of the compartment

$$
P_{2}=P_{A},+\rho_{a} g h=P_{A}+\rho_{a} g h
$$

Equations (A1) and (A2) give

$$
\mathrm{v}_{\mathrm{H}}=\left(2 / \rho_{\mathrm{H}}\right)^{1 / 2}\left[\left(\mathrm{P}_{1}-\mathrm{P}_{2}\right)+\mathrm{gh}\left(\rho_{\mathrm{a}}-\rho_{\mathrm{H}}\right)\right]^{1 / 2}
$$

or

$$
\frac{\mathrm{v}_{\mathrm{H}}}{\left[2 \mathrm{gh}\left(\rho_{\mathrm{a}}-\rho_{\mathrm{H}}\right) / \rho_{\mathrm{a}}\right]^{1 / 2}}=\left(\rho_{\mathrm{a}} / \rho_{\mathrm{H}}\right)^{1 / 2}\left[\left(\mathrm{P}_{1}-\mathrm{P}_{2}\right) / \operatorname{gh}\left(\rho_{\mathrm{a}}-\rho_{\mathrm{H}}\right)+1\right]^{1 / 2}
$$

Similarly, Figure A-2 is the one way inflow through the ceiling vent. Apply the Bernoulli's equation along the streamline between points 2 and $A$ which is at the Vena Contracta level and is at a distance $h$ below the ceiling vent (the datum level)

$$
P_{2}+\rho_{a} g h=P_{A}+1 / 2 \rho_{a} v_{a}^{2}
$$


Apply the Bernoulli's equation between points 1 and $A^{\prime}$ inside of the compartment

$$
\mathrm{P}_{1}+\rho_{\mathrm{H}} \mathrm{gh}=\mathrm{P}_{\mathrm{A}}, \quad=\mathrm{P}_{\mathrm{A}}
$$

Equations (A5) and (A6)

$$
\mathrm{v}_{\mathrm{a}}=\left(2 / \rho_{\mathrm{a}}\right)^{1 / 2}\left[-\left(\mathrm{P}_{1}-\mathrm{P}_{2}\right)+\mathrm{gh}\left(\rho_{\mathrm{a}}-\rho_{\mathrm{H}}\right)\right]^{1 / 2}
$$

or

$$
\frac{v_{a}}{\left[2 g h\left(\rho_{\mathrm{a}}-\rho_{\mathrm{H}}\right) / \rho_{\mathrm{a}}\right]^{1 / 2}}=\left[-\left(\mathrm{P}_{1}-\mathrm{P}_{2}\right) / \mathrm{gh}\left(\rho_{\mathrm{a}}-\rho_{\mathrm{H}}\right)+1\right]^{1 / 2}
$$

Equations (A4) and (A8) are the dimensionless outflow and inflow flow velocities through the ceiling vent. One way outflows through the ceiling vent with hot combustion gas and cool fresh air density ratios of $\rho_{\mathrm{H}} / \rho_{\mathrm{a}}=1 / 4$ and $\rho_{\mathrm{H}} / \rho_{\mathrm{a}}=1 / 2$ are plotted as the two curves on the upper half of Figure A3. For the purpose of better appearance, one way inflows through the ceiling vent, which are independent of density ratios $\rho_{\mathrm{H}} / \rho_{\mathrm{a}}$, resulted in only one curve plotted in the lower part of Figure A-3. 


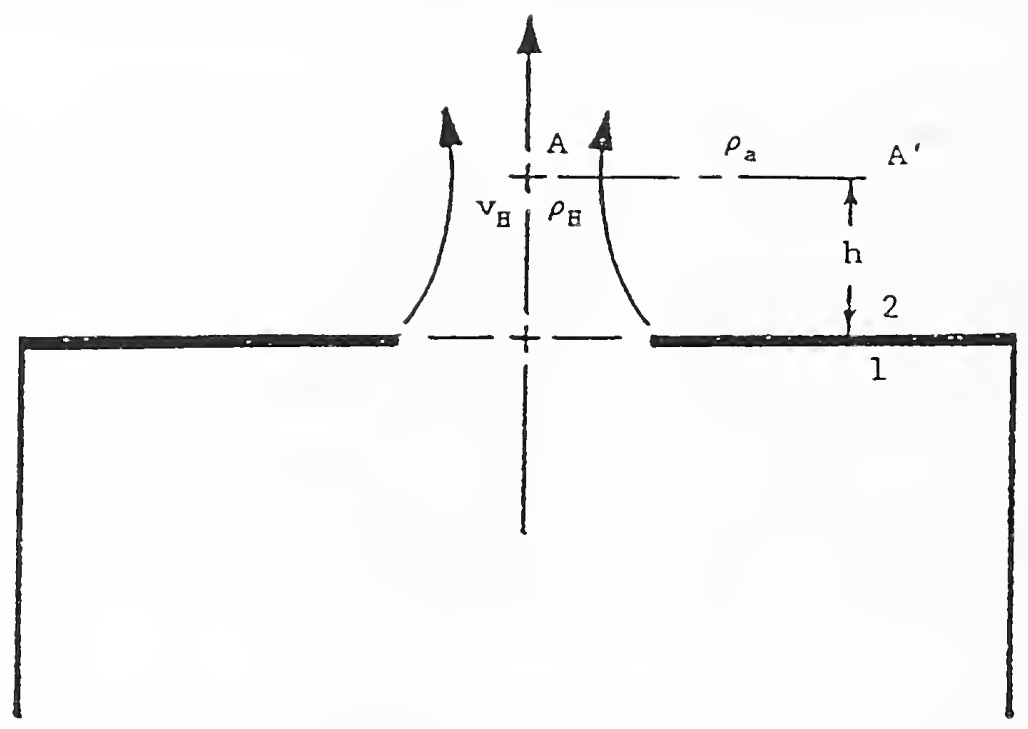

Figure A-1. One way Outflow Through the ceiling vent

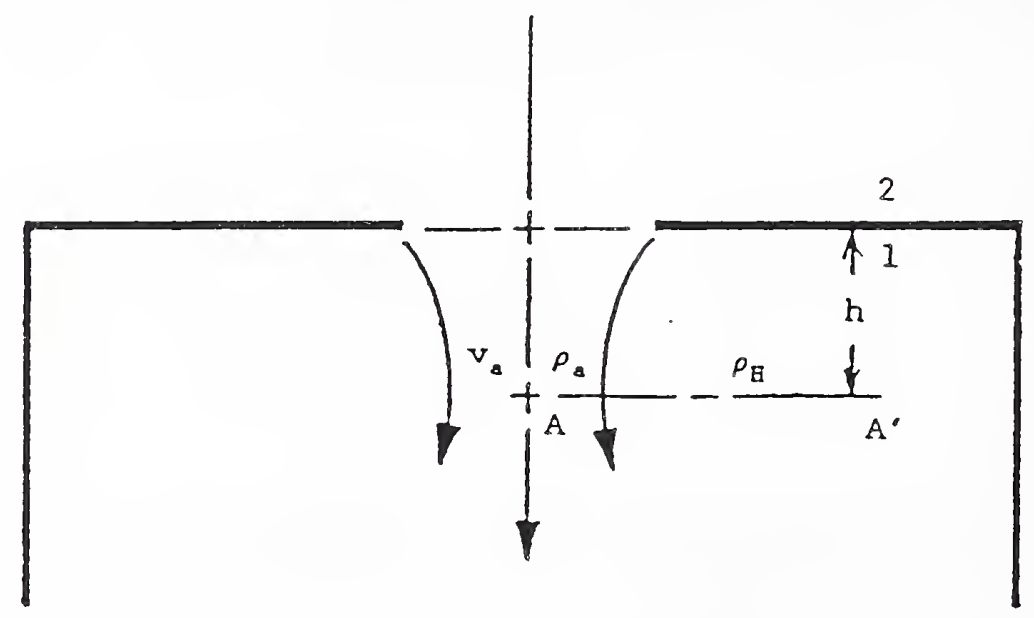

Figure A-2. One Way Inflow Through the Ceiling Vent 


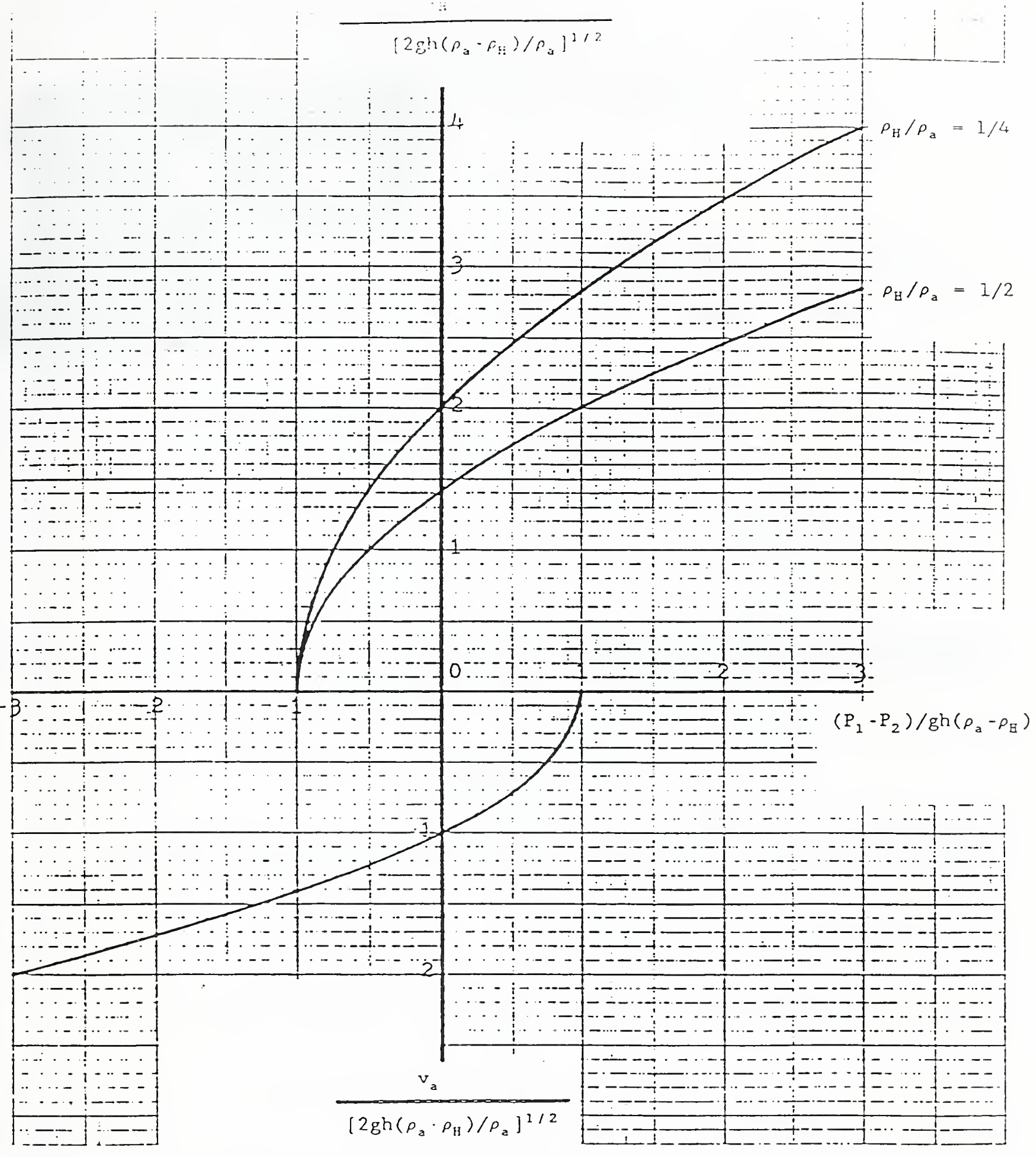

Figure A-3. Flow Velocity Through Ceiling Vent 
$\Delta \mathrm{P}=\mathrm{P}_{\mathrm{BOT}}-\mathrm{P}_{\mathrm{TOP}}$

For arbitrary $\Delta \rho=\rho_{\mathrm{TOP}}-\rho_{\mathrm{BOT}}$

$\mathrm{V}_{\mathrm{BOT}, \mathrm{ST}}=\mathrm{C}_{\mathrm{D}} \mathrm{A}_{\mathrm{V}}\left|2 \Delta \mathrm{P} / \rho_{\mathrm{BOT}}\right|^{1 / 2}, \quad \mathrm{~V}_{\mathrm{TOP}, \mathrm{ST}}=0$

if $\Delta P>0$

$\mathrm{V}_{\mathrm{BOT}, \mathrm{ST}}=0$,

$\mathrm{V}_{\mathrm{BOT}, \mathrm{ST}}=0$,

$$
V_{T O P, S T}=C_{D} A_{V}\left|2 \Delta P / \rho_{T O P}\right|^{1 / 2} \text { if } \Delta P<0
$$

$V_{\text {TOP }}=V_{\text {TOP,ST }}+V_{E X}$

$\mathrm{V}_{\mathrm{BOT}}=\mathrm{V}_{\mathrm{BOT}, \mathrm{ST}}+\mathrm{V}_{\mathrm{EX}}$

When the density configurations do not lead to an unstable hydrostatic configuration the standard model is valid. In particular,

$V_{E X}=0$ for arbitrary $\Delta \mathrm{P}$ if $\rho_{\mathrm{TOP}} \leq \rho_{\mathrm{BOT}}$

For the Figure $B-1$ scenario under the conditions $\rho_{\mathrm{TOP}}>\rho_{\mathrm{BOT}}$ and $\Delta \mathrm{P}=0$, Epstein [2] proposes the following for the exchange flow through horizontal circular vents:

$V_{E X}=0.055\left(g \Delta \rho D^{5} / \vec{\rho}\right)^{1 / 2} \quad$ if $\rho_{T O P}>\rho_{B O T}$ and $\Delta P=0$

where $D$ is the diameter of the vent, $g$ is the acceleration of gravity, and

$\bar{\rho}=\left(\rho_{\mathrm{TOP}}+\rho_{\mathrm{BOT}}\right) / 2$

In terms of the vent area, $A_{V}=\pi D^{2} / 4$, Equation (B8) can be written as

$V_{E X}=0.10\left\{g \Delta \rho A_{V} 5 / 2 / \bar{\rho}\right\}^{1 / 2}$ if $\rho_{T O P}>\rho_{B O T}$ and $\Delta P=0$

To the accuracy indicated, the data of Epstein [2] suggests that $V_{E x}$ for square vents can also be predicted by Equation (B8'). 


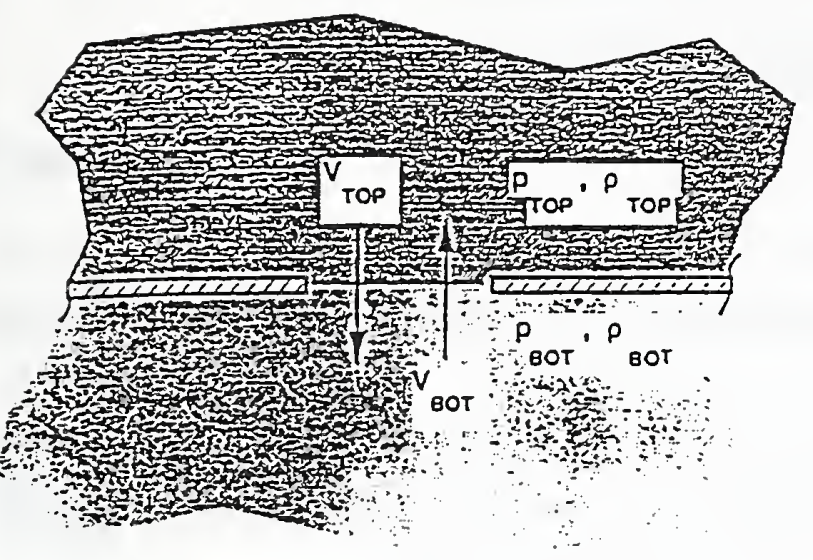

Figure B-1. The basic horizontal-vent configuration.

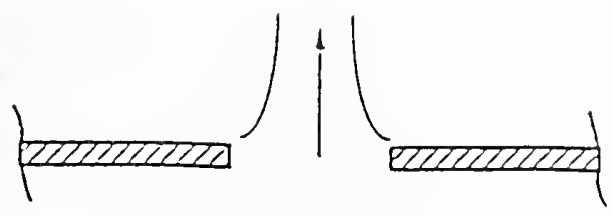

(a) $\Delta p>0: V_{\text {TOP.ST }}=0$

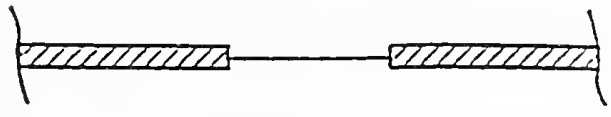

(b) $\Delta p=0: V_{\text {TOP,ST }}=V_{\text {BOT.ST }}=0$

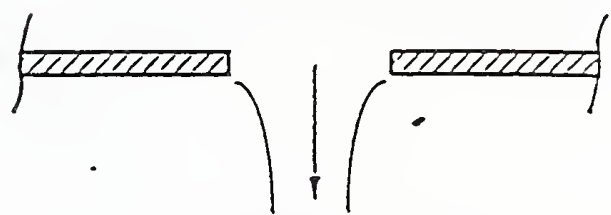

(c) $\Delta p<0: v_{\text {BOT.ST }}=0$

Figure B-2. The standard vent-flow model for horizontal vents.

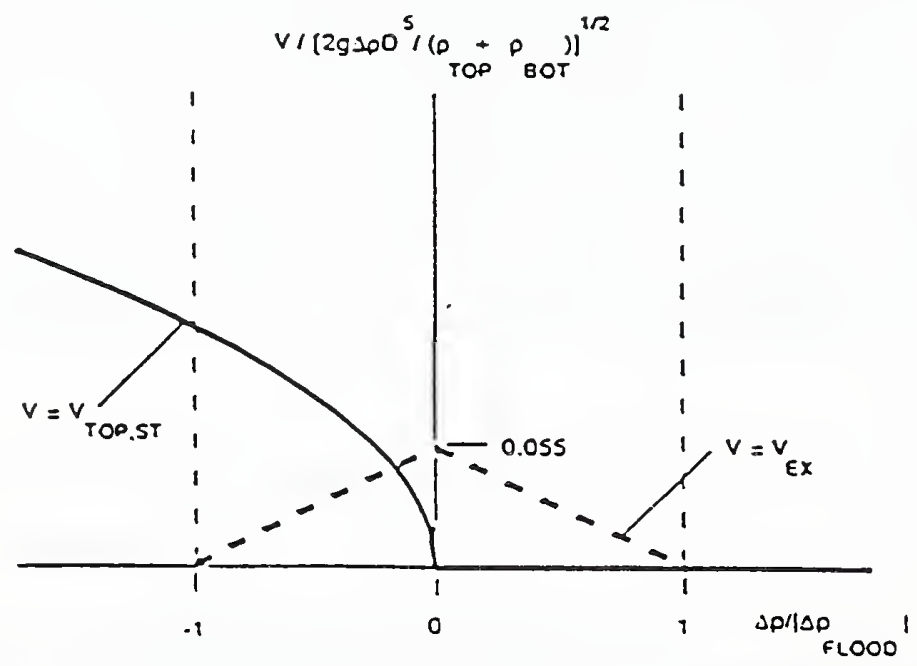

Figure B-3. The volume-flow-rate components $V_{T O P, S T}$ and $V_{E X}$ for unstable Figure-1 configurations, $\Delta p>0$, plotted as functions of $\Delta p^{\circ}$. 


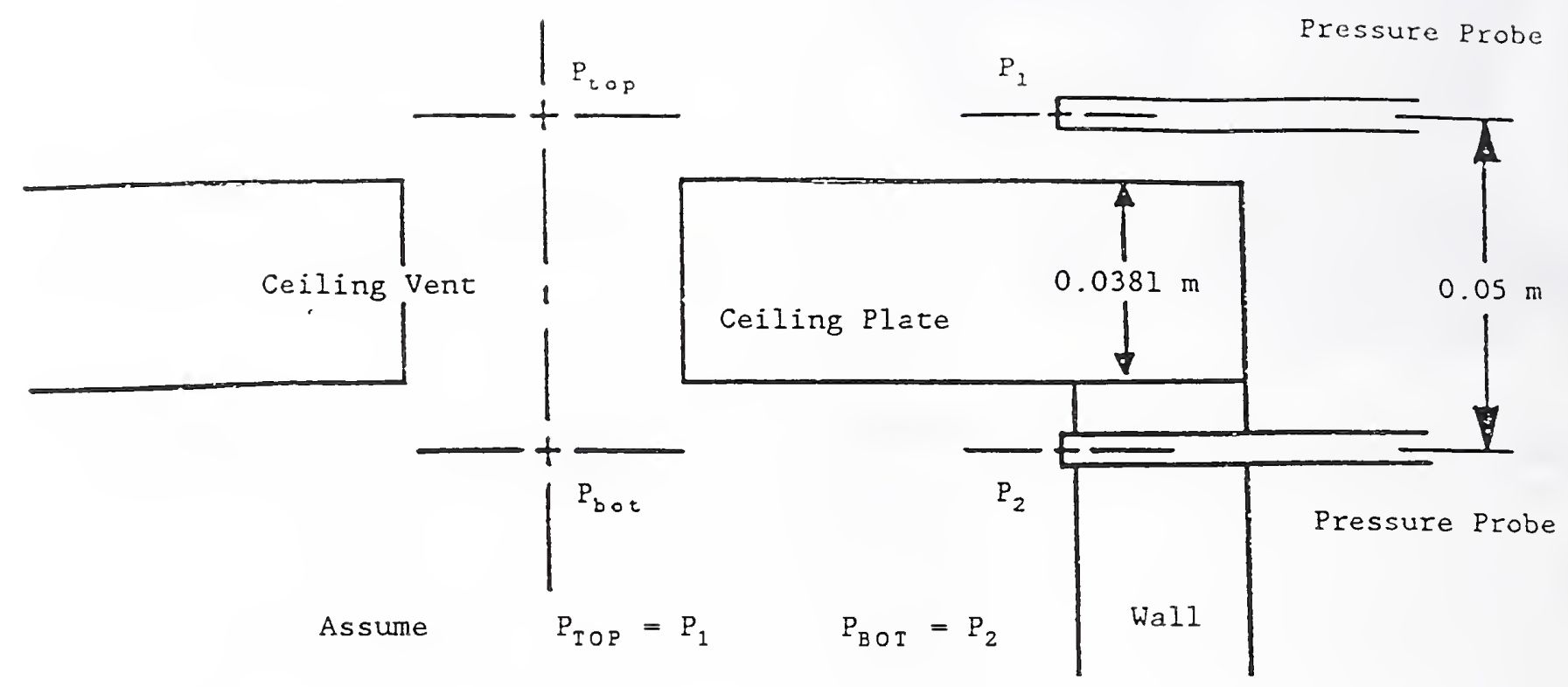

(1) Before compartment fire starts, there are no flows in or out across the ceiling vent. From Bernoulli's equation

$$
\begin{aligned}
P_{B O T} & =P_{T O P}+\rho_{O} g h \\
& =P_{T O P}+1.2 \mathrm{~kg} / \mathrm{m}^{3} \times 9.8 \mathrm{~m} / \mathrm{s}^{2} \times 0.05 \mathrm{~m} \\
& =P_{T O P}+0.588 \text { pascal } \\
P_{B O T} & -P_{T O P}=0.588 \text { pascal }
\end{aligned}
$$

(2) Define $D P=$ Differential Pressure $=P_{2}-P_{1}-0.588$ pascal

$$
\begin{aligned}
& \text { or } D P=P_{B O T}-P_{T O P}-0.588 \text { pascal } \\
& \text { (i) } D P=0 \quad \text { was set before compartment fire tests started } \\
& \text { (ii) } P_{B O T}-P_{T O P}=D P+0.588 \text { pascal during compartment fire tests }
\end{aligned}
$$

(3) For 4 in Dia. ceiling vent compartment fire tests

$$
\mathrm{P}_{\mathrm{BOI}}-\mathrm{P}_{\mathrm{IOP}}=(-0.333+0.588) \text { pascal }=0.255 \text { pascal }
$$

For 6 in Dia. ceiling vent compartment fire tests

$$
\mathrm{P}_{\mathrm{BOT}}-\mathrm{P}_{\mathrm{IOP}}=(-0.133+0.588) \text { pascal }=0.455 \text { pascal }
$$




\section{BIBLIOGRAPHIC DATA SHEET}

1. PUBUCATION OR AEPORT NUMBEA NISTIR 4499

2 PERFOAMING ORGAMIZATION REPORT MUMBER

3. PUEUCATION DATE

February 1991

4. TITLE AND SUDTITLE

An Experimental Study of Top Vented Compartment Fires

5. AUTHOA(S)

King-Mon Tu

6. PERFORLING ORQWMIZATION (IF JOINT OR OTHEA THAN MIST, SEE INSTRUCTIONS)

U.S. DEPARTMENT OF COMMENCE

MATIONAL IMSTITUTE OF STANDAADS AND TECHNOLOOY

CATHERSBURQ, MD 2009

7. CONTRACT/ORANT MULBER

2. TYPE OF REPORT AND PERIOD COVERED

9. SPONSORING ORQANIZATION MANE AND COMPUTE ADDRESS (STREET, CTT, STATE, עM)

11. ABSTRACT (A 200-WORD OA LESS FACTUAL SUMMARY OF MOST SIOMIFCANT IMFOAMATION. IF DOCUMENT INCLUDES A SIONIFICANT BIBUOCRAPHY OA UTERATURE SURVEY, MEMTION IT HERE)

In a top vented compartment fire, both density difference and pressure difference across the horizontal ceiling vent control the vent flow. This research work pursued experimental studies and investigations of exchange flows through a horizontal ceiling vent as related to solely top vented compartment fire situations. A cubic box with inside dimensions of $0.43 \mathrm{x}$

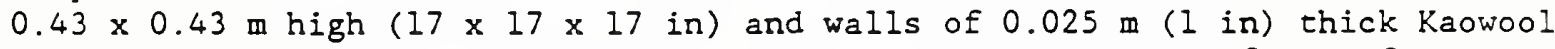
was employed for the compartment fire tests. For compartment fires of various horizontal ceiling vent sizes: (1) the fuel mass burning rates were measured, and (2) the air and combustion-flue-gas exchange flow rates were estimated based on [i] available theories and [ii] gas concentrations in the fire compartment.

12. KEY WORDS (6 TO 12 ENTRIES; ALPHABETICAL ORDEA; CAPTTALZE OMLY PROPER MAMES; AND SEPARATE KEY WORDS BY SEMICOLONS)

Ceiling Vents; Compartment Fires; Density Differential; Fire Models; Flow Rate;

Pressure Differential; Vents

FOR OFFICLAL DISTAIEUTION. DO NOT REEASE TO MATIONAL TECHMICAL IMFORMATION SERVICE (NTIS).

ORDER FMOM SUPEAINTENDENT OF DOCUMENTS, U.S. COVERMMENT PAINTIMC OFFICE, WASHINGTON..DC 20402

ORDER FROM MATIOMNL TECHMICAL INFORMATION SERVCE (NTIS), SPAIMGFIED, VA 22161.

14. MUMBER OF PRINTED PAGES 



\section{.}




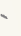

